\title{
STUDY FENOMENOLOGI: PSIKOLOGIS PASIEN KANKER YANG MENJALANI KEMOTERAPI
}

\author{
Lestari, Agustina ${ }^{1}$, Budiyarti,Yuliani ${ }^{2}$, Ilmi,Bahrul $^{3}$, \\ ${ }^{1}$ Mahasiswa Pascasarjana Ilmu Keperawatan Universitas Muhammadiyah Banjarmasin, \\ 70114, Indonesia \\ ${ }^{2}$ Staff Dosen Pascasarjana Universitas Muhammadyah Banjarmasin, 70114, Indonesia \\ ${ }^{3}$ Staff Dosen Politeknik Kesehatan Banjarmasin, 70714, Indonesia
}

Email: agustinalestaricb@gmail.com

\begin{abstract}
Abstrak
Latar Belakang: Tindakan yang sering dilakukan dalam penatalaksaan pasien kanker adalah Kemoterapi. Tindakan kemoterapi memiliki dampak terhadap fisik dan psikologis pasien kanker. Saat semua terfokus pada kondisi fisik saja, seringkali kondisi psikologis pasien terabaikan. Terganggunya kondisi psikologis akan memperburuk kondisi kesehatan pasien kanker. Penelitian ini bertujuan untuk mengekplorasi aspek psikologis pasien kanker yang menjalani kemoterapi.

Metode: Penelitian ini menggunakan metode kualitatif dengan pendekatan fenomenologi dimana pengumpulan data dilakukan dengan wawancara mendalam (indept interview). Partisipan yang digunakan sebanyak 8 orang yaitu pasien kanker yang menjalani kemoterapi dan hasilnya dianalisis menggunakan analisis Cresswel.

Hasil: Penelitian menemukan 10 tema yaitu (1) respon psikologis pasien saat terdiagnosa kanker, (2) proses pengambilan keputusan pengobatan pada pasien kanker, (3) faktor yang mempengaruhi proses pengambilan keputusan pengobatan, (4) respon psikologis pasien kanker selama menjalani kemoterapi, (5) dampak yang dialami pasien kanker selama menjalani kemoterapi, (6) upaya pasien kanker dalam menghadapi dampak yang dialami selama menjalani kemoterapi,(7) Dukungan keluarga dalam menghadapi dampak yang dialami selama menjalani kemoterapi, (8) keyakinan terhadap keberhasilan pengobatan, (9) perubahan yang dirasakan selama menjalani kemoterapi, (10) harapan selama menjalani pengobatan kemoterapi.

Kesimpulan : Dalam pemberian asuhan keperawatan pada klien kanker yang sedang menjalani kemoterapi, kondisi fisik dan psikologis pasien harus diperhatikan.
\end{abstract}

Kata Kunci: psikologis pasien kanker, kemoterapi 
Jurnal Keperawatan Suaka Insan | Volume 5 Edisi I, Juni 2020

PENDAHULUAN

\section{World Health Organitation (WHO)}

menguraikan angka kejadian kanker dari tahun ke tahun mengalami peningkatan dan masih menjadi masalah kesehatan di negara berkembang serta saat ini menjadi masalah kesehatan di dunia internasional. Hal ini disebabkan karena angka penderita kanker yang tinggi berkontribusi terhadap peningkatan angka kesakitan dan kematian serta sangat berpengaruh pada kualitas hidup penderitanya.

Data International Agency for Research on Cancer (IARC) kejadian kanker pada tahun 2012 sebanyak 14,1 juta kasus baru dengan mortalitas sebanyak 8,2 juta kasus, dan kejadian ini meningkat pada tahun 2018 menjadi 18,1 juta kasus baru disertai dengan peningkatan mortalitas sebanyak 9,6 juta kasus dimana kanker paru, payudara dan colorectum merupakan 3 jenis kanker terbanyak dan merupakan peringkat ke 5 teratas penyebab kematian. Riset Kesehatan Dasar (Riskesdas) dimana kejadian kanker pada tahun 2013 mencapai 1,4/1000 penduduk dan kemudian meningkat pada tahun 2018 menjadi 1,8/1000 penduduk. Peningkatan kejadian ini juga terjadi di Kalimantan Selatan dimana pada tahun 2013 penderita kanker sebanyak 1,6/1000 penduduk dan meningkat menjadi 2,13/1000 penduduk pada tahun 2018.

Kanker merupakan penyakit yang timbul akibat kesalahan sistem pembelahan ditingkat sel sehingga terjadi pertumbuhan sel yang abnormal dengan tingkat pertumbuhan yang terus menerus, tidak terkontrol, dapat berubah bentuk serta menyebar ke organ lainnya atau disebut metastase (Otto, 2015).

Beberapa tindakan yang dapat dilakukan untuk penanganan kanker diantaranya operasi, radioterapi dan kemoterapi. Pemberian kemoterapi dianggap lebih efektif karena obat langsung diberikan melalui pembuluh darah, sehingga dapat menjangkau sel-sel kanker yang telah bermetastase ke jaringan lainnya (Conti et, al, 2013). Hasil penelitian ini diperkuat Kim et al (2016) yang menyatakan bahwa kemoterapi sangat efektif diberikan untuk mencegah terjadinya metastase sel kanker pada organ yang lain.

Santi dan Sulastri (2010) menyatakan pengobatan dengan menggunakan tindakan kemoterapi pada pasien dengan kanker tidak hanya berdampak pada aspek fisik tetapi juga pada aspek psikologis. Wardani E.K (2014) menguraikan efek fisik yang dialami seperti mual, muntah, diare, konstipasi, alopesia, anemia, penurunan nafsu makan, toksisitas kulit, kelelahan, penurunan berat badan, neuropati perifer, perubahan rasa dan nyeri sedangkan efek psikologis diantaranya kecemasan, depresi, kesedihan, emosional, stres, harga diri rendah (self esteem) dan keputusasaan.

Yaribeygi, H. et al (2017) yang menyatakan bahwa stres sebagai salah satu efek psikologis merupakan faktor pemicu yang dapat memperburuk berbagai penyakit dan kondisi patologis, serta dapat menurunkan sistem kekebalan tubuh dimana stres bisa menurunkan aktivitas sitotoksik sel limfosit $\mathrm{T}$ sebagai sel pembunuh alami yang dapat meningkatkan pertumbuhan sel ganas pada penderita kanker, ketidakstabilan genetik, dan ekspansi tumor yang dapat memperburuk kondisi pasien.

Saniatuzzulfa dan Retnowati menguraikan bahwa proses penanganan pada pasien kanker seringkali hanya terfokuskan pada kesehatan fisik saja, sedangkan kesehatan 
Jurnal Keperawatan Suaka Insan | Volume 5 Edisi I, Juni 2020

psikologis pasien terkadang menjadi terabaikan, namun pada kenyataannya kesehatan psikologis sangat menunjang proses penyembuhan.

Pada saat pasien berespon secara psikologis terhadap penyakitnya maka pasien tersebut akan melewati 5 tahapan berduka seperti yang dikemukakan Ross (1969) yaitu pengingkaran (denial), marah (anger), tawar-menawar (bargaining), depresi (depression) dan penerimaan (acceptance). Selama menjalani tahapan berduka tersebut diperlukan suatu proses adaptasi terhadap perubahan yang terjadi untuk mempertahankan kondisi yang sehat dan seimbang. Sebagaimana model adaptasi Roy yang menguraikan agar dapat mempertahankan kehidupannya individu harus berespon positif terhadap perubahan lingkungan dengan melakukan adaptasi Alligood (2017).

Hasil studi pendahuluan yang dilakukan pada bulan September 2019 di ruang kemoterapi RSUD Ulin Banjarmasin, dengan cara wawancara mendalam kepada 5 orang pasien penderita kanker yang menjalani kemoterapi, dan didapatkan hasil hampir seluruhnya mengungkapkan selain mengalami dampak pada fisik juga mengalami masalah psikologis yang cukup berat dimulai sejak terdiagnosa kanker, dan masih dirasakan saat menjalani proses kemoterapi. Masalah psikologis tersebut diantaranya berupa ketidakberdayaan, kesedihan, rasa takut, gangguan body image, rendah diri, stres, depresi, putus asa, tidak ada gairah hidup hingga berniat untuk bunuh diri.

Besarnya dampak psikologis yang ditimbulkan dari proses pengobatan kanker dan ketidakmampuan untuk beradaptasi menyebabkan urgensinya tindakan penanganan masalah dilakukan pada semua aspek, salah satunya penanganan pada aspek psikologis. Maka pertanyaan penelitian ini adalah "Bagaimanakah psikologis pasien kanker yang menjalani kemoterapi”.

\section{METODE PENELITIAN}

Penelitian ini menggunakan pendekatan penelitian kualitatif dengan desain fenomenologi untuk menggali secara mendalam psikologis pasien kanker yang menjalani kemoterapi. Penentuan partisipan penelitian ini menggunakan teknik purposive sampling, yang berjumlah 8 partisipan pasien kanker yang menjalani kemoterapi. Penelitian dilaksanakan pada bulan September 2019- Januari 2020. Peneliti mengumpulkan data dengan cara wawancara mendalam (in-depth interview). Teknik penelitian menggunakan teknik analisis Cresswel.

\section{HASIL PENELITIAN}

Partisipan pada penelitian ini adalah pasien kanker yang menjalani kemoterapi. Total jumlah partisipan sebanyak 8 orang, yang terdiri dari 1orang laki-laki dan 7 orang perempuan, dengan usia termuda 30 tahun dan usia tertua 61 tahun. Tingkat pendidikan terendah adalah SD dan tertinggi adalah $\mathrm{S} 1$. Diagnosa pasien adalah $\mathrm{Ca}$. Mammae, Ca. Serviks, Ca. Ovarium, Ca. Colon dan PTG dengan kanker stadium III.

\section{Tabel 1 Karakteristik Partisipan}




\begin{tabular}{llllll}
\hline P & Usia & $\begin{array}{l}\text { Jenis } \\
\text { Kelamin }\end{array}$ & $\begin{array}{l}\text { Pendi } \\
\text { dikan }\end{array}$ & Diagnosa & $\begin{array}{l}\text { Sta } \\
\text { dium }\end{array}$ \\
\hline P1 & 52 & Perempuan & SD & Ca. mammae & III \\
\hline P2 & 47 & Perempuan & SMA & Ca. serviks & III \\
\hline P3 & 61 & Perempuan & SPRG & Ca. mammae & III \\
\hline P4 & 53 & Perempuan & SMA & Ca. serviks & III \\
\hline P5 & 40 & Laki-laki & SMA & Ca. Colon & III \\
\hline P6 & 30 & Perempuan & S1 & PTG & III \\
\hline P7 & 30 & Perempuan & SMA & Ca. mammae & III \\
\hline P8 & 48 & Perempuan & SMA & Ca. ovarium & III \\
\hline
\end{tabular}

Penelitian ini menghasilkan 10 buah tema sebagai berikut :

\section{Tema 1:}

Respon psikologis pasien saat terdiagnosa kanker

\section{Tema 2:}

Proses pengambilan keputusan pengobatan pada pasien kanker.

\section{Tema 3:}

Faktor yang mempengaruhi proses pengambilan keputusan pengobatan.

\section{Tema 4:}

Respon psikologis pasien kanker selama menjalani kemoterapi.

\section{Tema 5:}

Dampak yang dialami pasien kanker selama menjalani kemoterapi

\section{Tema 6:}

Upaya pasien kanker dalam menghadapi dampak yang dialami selama menjalani kemoterapi.

\section{Tema 7:}

Dukungan keluarga dalam menghadapi dampak yang dialami pasien kanker selama menjalani kemoterapi

\section{Tema 8:}

Keyakinan terhadap keberhasilan pengobatan.

\section{Tema 9:}

Perubahan yang dirasakan selama menjalani kemoterapi.

\section{Tema 10:}

Harapan selama menjalani pengobatan kemoterapi.

\section{PEMBAHASAN}

\section{Respon psikologis pasien saat terdiagnosa} kanker

Respon psikologis merupakan tanggapan, tingkah laku atau sikap terhadap stimulus (rangsangan) tertentu yang berkaitan dengan keadaan jiwa individu. Sejalan dengan adanya stimulus, tingkat adaptasi individu direspon sebagai suatu input dalam sistem adaptasi (Tomey dan Alligood, 2014).

Seseorang yang terdiagnosa penyakit kanker akan mengalami berbagai respon psikologis sebagai bentuk tanggapan terhadap stimulus yang ada. Pada penelitian ini terdapat beberapa respon psikologis yang dialami pasien saat dirinya terdiagnosa kanker diantaranya denial (penolakan), ansietas (cemas), mengisolasi diri, dan acceptance (penerimaan).

Sebagaimana teori berduka yang yang dikemukakan oleh Ross (1969) dimana terdapat 5 tahapan kesedihan ketika seseorang berduka yaitu : penolakan (denial), marah (anger), tawarmenawar (bargaining), depresi (depression) dan penerimaan (acceptance). Respon tiap individu dalam melalui tahap tersebut berbeda-beda tergantung faktor internal dan eksternal yang dapat mempengaruhi respon psikologisnya. Pasien penderita kanker yang mengalami respon psikologis, tidak jarang akan menjalani sebagian atau seluruh respon psikologis tersebut. 
(Afuiakani, et al, 2018). Dalam penelitian ini selain mengalami respon pada tahap berduka, pasien kanker juga mengalami kecemasan dan mengisolasi diri saat terdiagnosa kanker.

Denial yaitu respon penolakan yang biasanya hanyalah pertahanan sementara bagi individu. Pada penelitian ini respon denial ditunjukkan pasien kanker dengan rasa tidak percaya dengan penyakit yang menimpa dirinya serta merasa bingung akan apa yang harus dilakukan setelah terdiagnosa kanker. Seperti hasil penelitian Wulandari, et al, (2017) yang menyatakan bahwa perasaan negatif yang dimiliki oleh seorang penderita kanker adalah berupa perasaan kaget, sempat merasa drop, khawatir dan bingung ketika awal didiagnosis menderita kanker.

Kecemasan (ansietas) dalam hal ini juga merupakan respon psikologis yang dialami pasien saat terdiagnosa kanker berupa perasaan takut, sedih dan kesulitan tidur. Nurpeni, et al, (2014) dimana pasien penderita kanker akan merasakan kecemasan yang disebabkan karena adanya kekhawatiran akan menyebarnya sel-sel kanker ke organ lain dan persepsi masyarakat luas dimana kanker adalah penyakit ganas yang dapat menimbulkan kematian.

Pasien kanker juga seringkali mengisolasi diri mereka sendiri, bahkan mereka tidak ingin keadaannya diketahui orang lain. Sebagaimana penelitian Sasongko (2010) yang menyatakan bahwa penderita kanker cenderung menarik diri dari lingkungan sosialnya, karena merasa orang lain tidak akan bisa menerima dan mengerti dirinya, selain itu juga penderita kanker merasa dirinya menjadi beban berat bagi keluarganya sehingga membuat penderita kanker cenderung mengisolasi diri dari dunia luar.
Dampak yang terjadi pada tahap ini adalah kondisi penyakit akan menjadi lebih buruk, karena pasien yang tidak percaya dengan diagnosa, pasien akan mengabaikan pengobatan yang sebenarnya dapat menyembuhkan penyakit tersebut (Razali, et al, 2013). Kemampuan adaptasi dari pasien kanker sangat dibutuhkan dalam menjalani tahap-tahap respon tersebut. Tingkat kemampuan adaptasi tersebut tergantung dari stimulus yang didapat berdasarkan kemampuan individu, dan sangat tergantung pada pengalaman yang didapatkan sebelumnya, status kesehatan, dan stressor yang diberikan (Tomey dan Alligood, 2014).

\section{Proses pengambilan keputusan pengobatan pada pasien kanker}

Menurut Baron \& Byrne (2008) pengambilan keputusan adalah suatu proses melalui kombinasi individu atau kelompok dan mengintegrasikan informasi yang ada dengan tujuan memilih satu dari berbagai kemungkinan tindakan. Teori adaptasi Roy menjelaskan proses pengambilan keputusan pengobatan untuk pasien kanker ini termasuk dalam proses kontrol atau mekanisme koping khususnya pada subsistem kognator dimana subsistem kognator ini merupakan proses kontrol yang berhubungan dengan fungsi otak dalam memperoleh informasi, penilaian, emosi, penyelesaian masalah dan pengambilan keputusan dalam proses internal yang berhubungan dengan penilaian atau analisa (Tomey dan Alligood, 2014).

Menurut Solomon et al (2006), terdapat 5 tahap dalam melakukan pengambilan keputusan untuk pengobatan yaitu problem recognition 


\section{Jurnal Keperawatan Suaka Insan | Volume 5 Edisi I, Juni 2020}

(pengenalan masalah), information search (pencarian informasi), evaluation of alternative (evaluasi alternatif), purchase (keputusan menentukan pilihan), dan ourcome (hasil). Pada penelitian ini pasien kanker melewati beberapa tahap dalam proses pengambilan keputusan pengobatan yaitu problem recognation, evaluation of alternatif dan information search.

Problem recognation atau pengenalan masalah merupakan proses yang terjadi saat seseorang melihat perbedaan yang signifikan antara keadaan saat ini dan keadaan yang diinginkan atau yang dibutuhkan sehingga menjadi alasan melakukan pengobatan (Solomon et al, 2006). Hasen, et.al, (2008) mengemukakan berdasarkan konsep penyakit kanker itu sendiri, kecepatan pasien kanker dalam mengambil keputusan pengobatan terkait penyakitnya, sangat menentukan keberhasilan dari perawatan dan pengobatan penyakit kanker. Pernyataan tersebut diperkuat oleh Sari, L.T, (2019) yang menyatakan motivasi dan keinginan untuk sembuh dari pasien dianggap menjadi faktor yang sangat kuat membantu kesembuhan terutama pasien yang mematuhi pengobatan, kesembuhan itulah yang mendorong mereka untuk menyelesaikan dan mematuhi pengobatan yang di programkan.

Komponen penting lainnya adalah dukungan keluarga, sebagaimana penelitian Rahayuwati, et al, (2017) yang menyatakan bahwa pasien kanker juga sangat memerlukan dukungan keluarga dalam hal memutuskan pengobatan yang akan dijalani, sebagian pasien kanker tidak menentukan pilihan pengobatan sendiri atau mandiri. Setiap pilihan jenis pengobatan merupakan hasil diskusi dan kesepakatan dengan keluarga atau orang terdekat.
Information Search atau pencarian informasi merupakan tahap dimana pasien kanker mengumpulkan informasi sebanyak-banyaknya tentang penyakit yang dialami dan pengobatan yang akan ditempuhnya sebelum memutuskan untuk melakukan kemoterapi. Menurut Solomon et al, (2006) information search adalah proses seseorang mengamati lingkungan untuk mendapatkan suatu informasi sesuai dengan kebutuhan untuk membuat sebuah keputusan pengobatan. Aruan dan Isfandiari (2015) menyatakan defisiensi informasi dapat menyebabkan keterlambatan pengobatan pada kanker payudara sehingga mengakibatkan pasien datang setelah penyakit dalam stadium yang sudah parah.

Evaluation of alternatif atau evaluasi alternatif merupakan tahap dimana aktif atau tidaknya pasien kanker untuk mencari perbandingan pelayanan pengobatan. Penelitian Paratika dan Ernawaty (2018) dimana dalam memutuskan pengobatan pasien cenderung tidak melakukan perbandingan dengan fasilitas kesehatan lain, sehingga informasi yang didapatkan terkait dengan pelayanan pengobatan hanya berasal dari petugas kesehatan dan cenderung mengikuti alur dan saran dari petugas kesehatan saja sehingga informasi yang didapatkan terkait pengobatan tidak banyak diperoleh pasien.

Faktor yang mempengaruhi proses pengambilan keputusan pengobatan.

Dalam pengambilan suatu keputusan biasanya akan ada faktor-faktor yang dapat mempengaruhi proses seseorang melakukan pengambilan keputusan tersebut. Faktor-faktor tersebut dapat berasal dari faktor internal dan 


\section{Jurnal Keperawatan Suaka Insan | Volume 5 Edisi I, Juni 2020}

faktor eksternal diantaranya yaitu faktor pribadi, faktor psikologis, faktor budaya, maupun faktor social (Schiffman dan Kanuk, 2007).

Faktor pribadi meliputi usia, pekerjaan, kepribadian, dan gaya hidup. Faktor psikologis meliputi motivasi, persepsi, pembelajaran, memori, dan kepercayaan. Faktor budaya meliputi budaya, sub budaya, dan kelas sosial. Faktor sosial meliputi keluarga, peran, dan status (Notoatmojo, 2003).

Partisipan pada umumnya merasa bahwa penyakit yang mereka derita tidak berbahaya sehingga dirasa tidak perlu melakukan pengobatan atas penyakitnya. Kartini, et al (2019) menyatakan bahwa faktor predisposisi (predisposing factor) yang mempengaruhi keterlambatan pengobatan yaitu pendidikan pasien kanker yang rendah, serta sikap informan kurang merespon terhadap penyakitnya.

Hal ini sejalan dengan penelitian yang dilakukan Rahayuwati, et al, (2017), yang menyatakan hampir semua partisipan dalam penelitiannya mengungkapkan sebenarnya mereka merasakan gejala kanker relatif sudah lama, bahkan 8-10 tahun yang lalu, yang dirasakan pada awalnya adalah benjolan kecil saja disekitar payudara.

Faktor eksternal berupa keterbatasan biaya (ekonomi kurang) juga menjadi faktor yang dapat mempengaruhi pengambilan keputusan. Yani (2007) menyatakan bahwa sedikitnya pengetahuan tentang kanker membuat kesadaran penderita untuk melakukan perawatan lebih dini rendah dan kebutuhan financial menjadi salah satu faktor yang ditakuti oleh penderita kanker karena biaya yang besar untuk pengobatan.
Kurang dukungan untuk berobat juga dialami pasien kanker dalam penelitian ini. Padahal pasien dengan penyakit kanker membutuhkan dukungan keluarga karena kondisi psikologis yang dialami akibat beban fisik dan emosional yang dialami pasien. Sebagaimana penelitian Yanti dan Kholimah (2016) yang mengatakan bahwa dukungan keluarga mempunyai pengaruh yang baik untuk proses pengobatan kanker.

Sebagaimana teori adaptasi Roy pada proses kontrol (mekanisme koping), faktor yang mempengaruhi proses pengambilan keputusan pengobatan ini berada pada subsistem kognator terkait dengan kemampuan pasien untuk pengambilan keputusan, dimana apabila pasien kanker dapat berprilaku adatif maka faktor-faktor yang mempengaruhi ini akan dapat diatasi dengan baik sehingga pertolongan terhadap penyakit yang di derita cepat teratasi.

\section{Respon psikologis pasien kanker selama menjalani kemoterapi}

Sebagaimana respon psikologis yang dialami pasien kanker saat terdiagnosa kanker, pasien juga akan mengalami beberapa respon psikologis selama menjalani kemoterapi. Dalam penelitian ini terdapat beberapa respon psikologis yang dialami pasien saat dirinya menjalani pengobatan kemoterapi diantaranya yaitu denial (penolakan), ansietas (cemas), anger (marah), dan acceptance (penerimaan).

Respon denial dimana pasien kanker masih merasa tidak menerima dengan penyakit dan pengobatannya sehingga menganggap bahwa dirinya belum memerlukan terapi tersebut dapat disebut sebagai salah satu stimulus kontekstual dalam teori adaptasi Roy, dimana menurut 


\section{Jurnal Keperawatan Suaka Insan | Volume 5 Edisi I, Juni 2020}

Halimatussakdiah dan Junardi (2017) menyatakan bahwa stimulus kontekstual pada pasien kanker yang menjalani kemoterapi diantaranya adalah ketidak patuhan pasien dalam program pengobatan kemoterapi dimana hal tersebut dipengaruhi oleh konsep diri, biaya, dukungan keluarga dan kerabat, serta efek samping yang dirasakan.

Kecemasan selama menjalani kemoterapi juga diungkapkan pasien kanker. Kecemasan yang berupa perasaan takut ini yaitu takut akan keganasan penyakit dan takut akan kematian yang mungkin dialaminya selama menjalani proses pengobatan. Permanawati dan Hertinjung (2015) menyatakan bahwa pasien kanker khususnya kanker payudara merasa takut terhadap risiko dari tindakan bedah yang akan dilakukan berupa kematian pasca operasi.

Respon anger atau marah juga ditunjukkan pasien kanker dalam penelitian ini. Bila rasa marah tersebut diterima dengan respon yang adatif maka pasien kanker dapat mengontrol emosinya akan tetapi bila diterima dengan respon maladaptif, maka akan menyebabkan akibat lain terhadap kondisi psikologis pasien kanker. Menurut Margaret and Mitchell (2004) bila respon kemarahan menjadi maladaptif, pasien kanker cenderung akan melakukan tindakan kekerasan, menyendiri, mengalami depresi berkepanjangan, bahkan hingga berisiko tinggi bunuh diri.

Berbeda dengan ketika pertama kali terdiagnosa pasien lebih banyak berespon negatif terhadap stimulus yang ada berupa penyakit kanker yang baru saja diketahui menimpa dirinya. Pada saat pasien kanker menjalani kemoterapi sebagian besar pasien kanker dalam penelitian ini sudah lebih bisa menerima (acceptance) terhadap proses pengobatan. Pada tahap ini sikap optimis klien terhadap pengobatan akan berdampak baik pada kesehatannya (Razali, et al, 2013). Pasien kanker yang optimis akan lebih dapat menerima kondisinya dibandingkan mencoba lari dari kondisi sakitnya (Hjelle \& Zeigler, 1992 dalam Saniatuzzulfa, et al, 2015).

\section{Dampak yang dialami pasien kanker selama menjalani kemoterapi}

Penelitian ini menunjukkan dampak yang dialami pasien kanker selama menjalani kemoterapi yaitu dampak fisik dan psikologis. Hal ini sebagaimana penelitian Santi dan Sulastri (2010) yang menyatakan pengobatan dengan menggunakan tindakan kemoterapi pada pasien dengan kanker tidak hanya berdampak pada aspek fisik tetapi juga pada aspek psikologis.

Ambarwati dan Wardani, W. N. (2014) yang menyatakan dampak yang terjadi akibat pengobatan kemoterapi pada fisik atau tubuh pasien yaitu mual dan muntah, konstipasi, neuropati perifer (kebas/ kesemutan), toksisitas kulit (kulit terlihat menghitam), alopesia atau kerontokan rambut, penurunan berat badan, kelelahan (fatigue), penurunan nafsu makan, nyeri, dan perubahan rasa.

Dampak selain pada fisik, kemoterapi juga berdampak pada psikologis. Penderita kanker dipaksa untuk menghadapi banyak serangan terhadap citra tubuh sepanjang perjalanan penyakit dan pengobatan, kerontokan rambut, kakeksia (emasiasi), perubahan kulit, perubahan pola komunikasi, dan disfungsi seksual adalah beberapa akibat menyulitkan dari kanker dan pengobatannya yang dapat mengancam harga diri dan citra tubuh penderita kanker sehingga dapat sangat berpengaruh terhadap psikologis pasien kanker (Smeltzer and Bare, 2008). 


\section{Jurnal Keperawatan Suaka Insan | Volume 5 Edisi I, Juni 2020}

Upaya pasien kanker dalam menghadapi dampak yang dialami selama menjalani kemoterapi.

Upaya dalam menghadapi dampak yang dialami pasien kanker selama menjalani kemoterapi pada penelitian ini adalah berupa upaya dari aspek biologis, upaya dari aspek psikologis, upaya dari aspek sosial dan upaya dari aspek spiritual. Koping dibutuhkan pasien sebagai upaya menghadapi dan menyikapi perubahan fisik dan psikologis yang diakibatkan efek kemoterapi, pasien memerlukan koping yang baik agar terapi menjadi efektif (Aufa, 2010).

Aspek biologis Distinarista (2017) seorang penyitas kanker menyampaikan cara efektif dalam mengatur pola makan dan asupan nutrisi bagi penderita kanker diantaranya tidak makan makanan yang dapat menunjang kanker. tahapan mekanisme kedua yang dilakukan suvivor kanker adalah pengobatan komplementer dan herbal.

Aspek psikologis Hodges \& Winstanley (2012) menguraikan bahwa pasien kanker yang memilih optimisme sebagai salah satu strategi koping memiliki efek langsung pada pasien kanker. Pasien yang berpikiran positif memiliki semangat juang yang tinggi untuk sembuh. Optimisme, dukungan sosial dan semangat juang memiliki pengaruh positif yang signifikan pada penderita kanker.

Upaya dari aspek sosial juga sangat penting bagi pasien kanker, sejalan dengan Damayanti et al (2008) yang menyatakan kondisi psikologis dan sosial yang normal dan stabil, secara langsung ataupun tidak langsung akan dapat meningkatkan kualitas hidup pasien kanker.

Upaya lainnya adalah dari aspek spiritual juga dilakukan dalam menghadapi dampak yang dialami pasien kanker selama menjalani kemoterapi yaitu dengan lebih mendekatkan diri kepada Tuhan yang Maha Esa melalui ibadah yang dilakukan. Agama dan spritualitas dipercaya dan dipraktekan dapat memainkan peran terhadap serangan stress dan koping karena adanya suatu penyakit (Manshaee \& Amini, 2013)

\section{Dukungan keluarga dalam menghadapi dampak yang dialami selama menjalani kemoterapi.}

Dukungan keluarga dalam menghadapi dampak yang dialami pasien kanker selama menjalani kemoterapi adalah dengan memberikan dukungan sebagaimana Song, Son, \& Lin (2011) yang menguraikan bahwa konseptualisasi dari dukungan keluarga merupakan konsep dukungan sosial, ada empat aspek dukungan keluarga yaitu dukungan emosional (seperti: caring, empati, cinta, dan kepercayaan); dukungan instrumental (seperti : tindakan termasuk menyediakan kebutuhan dan pelayanan yang terbaik); dukungan informasional (seperti: nasehat, informasi dan saran sebaik mungkin); dukungan appraisal (seperti: membangun hubungan timbal balik yang dapat digunakan untuk evaluasi diri).

Saragih (2010) pada pasien kanker yang menjalani kemoterapi bahwa berdasarkan dukungan emosional keluarga dalam kondisi baik yaitu 52\% pasien menerima dukungan emosional dari keluarga. Terdapatnya dukungan dari keluarga akan membuat pasien tidak merasa sendiri dan pasien merasa bebannya berkurang karena dapat mencurahkan segala yang dirasakannya kepada keluarga.

Dukungan instrumental berupa bantuan material seperti memberikan pertolongan langsung seperti meminjamkan atau memberikan uang, makanan dan layanan kesehatan. Bentuk 


\section{Jurnal Keperawatan Suaka Insan | Volume 5 Edisi I, Juni 2020}

dukungan ini mengurangi stress karena individu langsung dapat memecahkan masalahnya (Sarafino \& Smith, 2011). Dukungan lainnya yaitu memberikan dukungan informasional berupa informasi tentang pengobatan lain, dimana keluarga berupaya untuk membantu pasien menghadapi dampak selama menjalani kemoterapi dengan menyarankan pengobatan tradisional. Sebagaimana penelitian Shabrina dan Iskandarsyah (2019) yang menyatakan bahwa rekomendasi atau saran untuk menjalani pengobatan tradisional sebagian besar adalah dari anggota keluarga.

Dukungan appraisal dimana keluarga bertindak sebagai sistem pembimbing umpan balik. Dukungan ini terjadi melalui ekspresi penghargaan yang positif melibatkan penyataan setuju dan penilaian positif terhadap ide-ide, perasaan dan performa orang lain yang berbanding positif antara individu dengan orang lain (Sarafino \& Smith, 2011).

\section{Keyakinan terhadap keberhasilan pengobatan}

Keyakinan akan kesembuhan merupakan bentuk output dalam model adaptasi Roy. Adaptasi sangat dibutuhkan oleh pasien kanker terhadap kondisinya, salah satu faktor yang mempengaruhi adaptasi seorang yang menderita kanker adalah optimisme terhadap kesembuhan.

Pada saat menghadapi penyakit pasien kanker menyatakan lebih meningkatkan ibadah dan memasrahkan pada Tuhan akan kesembuhannya. Sejalan dengan Yani (2007) yang menyatakan sembahyang atau berdoa, membaca kitab suci dan praktek keagamaan lainnya sering membantu memenuhi kebutuhan spritual yang juga merupakan suatu perlindungan terhadap tubuh.
Anggraini, L (2018) menguraikan bahwa kepercayaan diri pasien kanker merupakan keyakinan terhadap kemampuan yang dimiliki oleh diri sendiri. Pernyataan ini diperkuat Ayurini dan Parmitasari (2015) dalam hasil penelitiannya menyatakan bahwa kepatuhan pasien juga sangat dipengaruhi oleh faktor dalam diri subjek sendiri yaitu keyakinan akan kesembuhan.

Bakoil (2014) dalam penelitiannya menyatakan pasien kanker memiliki keyakinan dan sikap untuk sembuh dari penyakitnya dan mempertahankan hidup mereka dengan memiliki pikiran positif, keyakinan akan pengobatan yang dijalani, kemauan untuk sembuh dan tidak mengalah pada penyakit kanker yang mereka derita. Keyakinan terhadap keberhasilan pengobatan juga muncul atas pengaruh dari luar diri pasien kanker. Distinarista keberhasilan para survivor cancer memperoleh kesembuhan dapat memotivasi pasien kanker lain untuk terus dapat yakin dan selalu berusaha mencapai kesembuhannya. Sehingga dengan melihat keberhasilan pengobatan yang orang lain dapat membuat pasien kanker yakin akan kesembuhan yang juga akan diperolehnya dengan menjalani pengobatan khususnya dengan kemoterapi.

Keyakinan pada pengobatan yang diberikan dokter juga menjadi keyakinan yang muncul dari luar diri pasien kanker dimana Elizabeth, et al (2015) menyatakan dalam penelitiannya bahwa pasien kanker yang berobat menunjukkan tingkat kepercayaan yang tinggi terhadap pengobatan medis dan kepada dokter.

Perubahan yang dirasakan selama pengobatan kemoterapi 


\section{Jurnal Keperawatan Suaka Insan | Volume 5 Edisi I, Juni 2020}

Perubahan kondisi fisik dan psikologis kearah yang lebih baik dirasakan pasien kanker selama menjalani kemoterapi. Dalam model adaptasi Roy ini termasuk dalam proses output terhadap kemampuan beradaptasi pasien dimana pada dalam hal ini respon adatif adalah respon yang ditampakkan pasien. Respon yang adaptif dapat meningkatkan integritas seseorang yang secara keseluruhan dapat terlihat bila seseorang tersebut mampu melaksanakan tujuan yang berkenaan dengan kelangsungan hidup, perkembangan, reproduksi dan keunggulan (Tomey dan Alligood, 2014).

Efek kemoterapi pada penyakit kanker membuat pasien kanker merasa lebih nyaman karena perubahan yang lebih baik pada keluhankeluhan fisik yang sebelumnya telah dialaminya. Keluhan-keluhan yang dialami sebelumnya ada yang dirasakan berkurang dan bahkan ada yang sudah menghilang (Kolin, et al, 2016). Pengobatan kemoterapi sebagai terapi paliatif, dilakukan untuk memperbaiki kualitas hidup pasien kanker yang diharapkan dapat meredakan nyeri dan gejala lain untuk sementara waktu (Kowalak, 2011). Pernyataan ini diperkuat Kolin, et al (2016) yang menyatakan dalam penelitiannya bahwa partisipan memperoleh manfaat dari kemoterapi walaupun tidak berlangsung terus menebus hal ini disebabkan karena efek toksisitas dari kemoterapi tetap saja tidak dapat membunuh semua sel kanker.

Selain kondisi fisik yang membaik, kemoterapi juga menyebabkan perubahan kondisi psikologis kearah yang lebih baik. Berpikir positif selama menghadapi keadaan yang sulit ketika menjalani kemoterapi adalah hal yang tidak mudah. Pasien kanker yang menjalani kemoterapi seringkali lebih banyak menunjukkan emosi negatif daripada emosi yang positif. pasien kanker memang harus sering berpikir positif terhadap dirinya dan penyakit yang ia derita walapun itu memang tidak mudah (Kolin, et al, 2016).

\section{Harapan selama menjalani pengobatan kemoterapi.}

Rahayuwati, et al, (2017) menyatakan dalam melihat proses kesembuhan yang akan pasien kanker terima setelah kemoterapi hampir seluruhnya menyatakan positif mereka mempunyai harapan untuk sembuh setelah berjuang dengan cara menjalani kemoterapi. Penelitian Kirana (2016) juga menambahkan bahwa pasien kanker memiliki harapan dan keyakinan untuk sembuh sehingga tidak harus menjalani pengobatan kemoterapi lagi, dan dapat melanjutkan hidup dengan lebih baik. Harapan subjek ingin sembuh dapat memberikan efek positif dan menjadikan energi untuk mengatasi efek buruk dari kemoterapi.

Harapan terhadap pasangan dan anggota keluarga juga diungkapkan pasien kanker dalam penelitian ini. Dukungan keluarga merupakan sikap, tindakan dan penerimaan keluarga terhadap anggota keluarganya yang bersifat mendukung selalu siap memberikan pertolongan dan bantuan jika diperlukan. Dalam hal ini penerima dukungan keluarga akan tahu bahwa ada orang lain yang memperhatikan, menghargai dan mencintainya. (Friedman, 2010).

Pasien kanker mengutarakan harapannya terhadap pelayanan kesehatan, pasien kanker mengatakan tenaga kesehatan harus lebih caring terhadap pasien. Anjaryani (2009) menganggap perawat yang dapat memberikan kepuasan kepada pasien adalah perawat yang bisa mengerti kondisi pasien, sabar, lemah lembut, memberikan 


\section{Jurnal Keperawatan Suaka Insan | Volume 5 Edisi I, Juni 2020}

semangat, dan memperhatikan kondisi pasien kanker secara keseluruhan.

Perawat mempunyai peran penting dalam mengkaji dan menangani masalah-masalah yang dialami oleh pasien yang menjalani kemoterapi karena efek sistemik yang menyebar luas, sehingga mempengaruhi banyak sistem tubuh. Perawat juga mendorong pasien dan anggota keluarga untuk bersedia mengkomunikasikan atau membicarakan, menceritakan dan mendiskusikan kekhawatiran terkait pengobatan kemoterapi (Smeltzer \& Bare, 2008).

Pemberian informasi tentang penyakit juga sangat diperlukan oleh pasien. Amelia, et al (2016) menyatakan bahwa pemberian informasi yang jelas dan mudah dimengerti serta pelayanan kepada pasien tanpa memandang status sosial dan lain-lain merupakan hal yang perlu ditingkatkan pelaksanaannya oleh pihak rumah sakit. Harapan merupakan sikap optimis yang ditunjukkan oleh pasien kanker dalam penelitian ini menunjukkan resiliensi atau kemampuan beradaptasi yang baik sehingga mampu menghadapi masalah-masalah yang dialami, mampu mengontrol diri dan mampu mengolah stres dengan mengubah cara berpikir saat mengalami stres.

\section{KESIMPULAN}

Tema yang dihasilkan tersebut sudah menjawab tujuan dari penelitian yaitu bagaimana psikologis pasien kanker selama menjalani kemoterapi. Pada penelitian ini didapatkan berbagai macam pernyataan partisipan terkait psikologis selama dirinya menjalani kemoterapi.

Pasien diharapkan mampu beradaptasi pada setiap dampak yang dialaminya baik fisik maupun psikologis selama menjalani proses pengobatan. Kemampuan beradaptasi pada pasien dan keinginan untuk sembuh dari pasien dapat menjadi faktor yang sangat kuat dalam membantu kesembuhan terutama pasien yang mematuhi pengobatan.

Hasil penelitian ini menekankan pentingnya peran perawat dalam memberikan asuhan keperawatan pada klien dengan kanker yang sedang menjalani kemoterapi. Khususnya dalam penerapan asuhan keperawatan untuk diagnosa perawatan yang tidak hanya terkait fisik tetapi juga psikologis pasien.

Institusi pendidikan perlu meningkatkan kemampuan dan keterampilan peserta didik dalam melakukan asuhan keperawatan pada pasien dengan kanker khususnya terhadap psikologis pasien selama menjalani kemoterapi. Hasil penelitian ini dapat digunakan sebagai masukan dalam pengembangan ilmu keperawatan dan penyusunan standar asuhan keperawatan dan standar pendidikan kesehatan pada pasien maupun keluarga.

\section{DAFTAR RUJUKAN}

Afuiakani, M. S., H. M. A. Djohgo, dan M. Y. Bina. (2017). Studi Fenomenologi Respon Psikologis Kubler Ross pada Pasien Kanker di RSUD Prof. Dr. W. Z. Johannes Kupang. CHMK Nursing Scientific Journal. Vol. 2, No. 2. http://cyber-

chmk.net/ojs/index.php/ners/article/view /160/134. Diakses 20 Januari 2020

Alligood, M.R. (2014). Nursing theorists and their work.8th ed.Hamid, Achir. Y., \& Ibrahim, Kusman. (2017). Pakar Teori Keperawatan dan Karya Meraka vol 1. Singapore: Elsevier. pp. 119-148

Ambarwati, dan Wardani, W.N. 2014, Efek Samping Kemoterapi Secara Fisik Pasien Penderita Kanker Serviks. Journal Ners. 10(1) 48-60. https://jurnal.unimus.ac.id/index.php/psn 
$\underline{12012010 / \text { article/view/1428/1481 }}$

Diakses 20 Januari 2020

Amelia, R., Hamsah, H., Betan, B. A. (2016). Persepsi Pasien Rawat Inap Terhadap Mutu Pelayanan Rumah Sakit Umum Daerah Dara' Kabupaten Polewali Mandar. Journal of Islamic Nursing. Volume 1, Nomor 2. http://journal.uinalauddin.ac.id/index.php/join/article/vie w/4963 Diakses 21 Januari 2020

Anggraini, L. (2018). Kepercayaan Diri Pasien Kanker yang Menjalani Kemoterapi. Universitas Muhammadiyah Surakarta. http://eprints.ums.ac.id/66804 Diakses 22 Januari 2020.

Anjaryani, W. D. (2009). Kepuasan Pasien Rawat Inap Terhadap Pelayanan Perawat Di RSU Tugurejo Semarang. Tesis. http://eprints.undip.ac.id/23824 Diakses 20 Januari 2020.

Aruan, P, K., Isfandiari, A, M. (2015). Hubungan Dukungan Sosial Terhadap Pengobatan Kanker Payudara di Yayasan Kanker Wisnuwardhana. Jurnal Promkes. Vol 3, No 2. 218-228. https://ejournal.unair.ac.id/index.php/PROMKE S/article/view/4469 Diakses 20 Januari 2020

Ayurini, I, R., Parmitasari, N,L,D. (2015). Kepatuhan Pengobatan Pada pasien kanker. Psikodimensia. Vol. 14/2. http://journal.unika.ac.id/index.php/psi/a rticle/viewFile/973/649 Diakses 20 Januari 2020

Bakoil, B, M. (2014). Upaya Mempertahankan Kelangsungan Hidup Penderita Kner Serviks di Rumah Sakit Umum Daerah Prof. DR. W.Z. Johannes Kupang. Jurnal MKMI, hal 71-79. http://journal.unhas.ac.id/index.php/mk mi/article/view/483 Diakses 22 Januari 2020.

Baron dan Byrne. (2008). Psikologi Sosial: Jilid 1 Edisi Kesepuluh. Jakarta: Penerbit Erlangga.

Conti, R. M., Bernstein, A. C., Villaflor, V. M., Schilsky, R. L., Rosenthal, M. B., \& Bach, P. B. (2013). Prevalence of offlabel use and spending in 2010 among patent-protected chemotherapies in a population-based cohort of medical oncologists. Journal of Clinical Oncology, 31(9), 1134-1139. https://doi.org/10.1200/JCO.2012.42.72 52. Diakses 20 April 2019

Damayanti, A, D., Fitriyah., Indriani. (2008). Penanganan Masalah Sosial dan Psikologis Pasien Kanker Stadium Lanjut dalam Perawtaan Paliatif. Indonesian Journal of Cancer. Volume 2, No 1. https://indonesiajournalof cancer.or.id/ejournal/index.php/ijoc/article/view/36. Diakses 03 Februari 2020

Distinarista, H., Anggorowati, Mardiyono, Dwidiyanti, M., Achsan, M., Sofro, U. (2017). Pengalaman Survivor Cancer: Studi Fenmenologi. Jurnal Keperawatan Soedirman (The Soedirman Journal of Nursing). Volume 12, No 3. http://jks.fikes.unsoed.ac.id/index.php/jk s/article/view/753 Diakses 22 Januari 2020

Elizabeth, Novie Nurbeti, N., Tejoyuwono, T. A. A. (2015). Tingkat Kepercayaan Pasien Kanker terhadap Pengobatan Medis di RSUD dr. Soedarso Pontianak. Jurnal Cerebellum. Volume 1 Nomor 1. https://media.neliti.com/media/publicati ons/192900 Diakses 22 Januari 2020.

Friedman, M.M., Bowden, R.V., \& Jones, G.E. (2010). Buku Ajar Keperawatan Keluarga; Riset, Teori, \& Praktik. Edisi 5. Jakarta: EGC.

Halimatussakdiah, dan Junardi. (2017). Faktor Risiko Kepatuhan Kemoterapi Pada Pasien Kanker Payudara. Jurnal Kesehatan. 8(3) 415-424. Politeknik Kesehatan Kementrian Kesehatan Tanjung Karang. http://ejurnal.poltekkestjk.ac.id/index.php/JK/article/view/654. Diakses 22 November 2019.

Hasen. (2008). Sosioeconomic patient chatacteristics predict delay in cancer diagnosis : a Danish cohort study. BMC Health Services Researchl, 8,49. doi : 10.1186/1472-6963-8-49.

https://www.researchgate.net/publicatio n/5544219. Diakses 20 Januari 2020. 
Hodges, K., \& Winstanley, S. (2012). Effects of optimism, social support, fighting spirit, cancer worry and internal health locus of control on positive affect in cancer survivors: A path analysis. Stress and Health, 28(5), 408-415. https://www.ncbi.nlm.nih.gov/pubmed/2 $\underline{3129560}$ Diakses 21 Januari 2020.

IARC (2013). Date Word of Cancer.http://gco.iarc.fr/ - Diakses 30 September 2019.

(2018). Date Word of Cancer.http://gco.iarc.fr/ - Diakses 10 Agustus 2019.

Kartini., Lubis, L. N., Moriza, T. (2019). Analisis Faktor Yang Mempengaruhi Keterlambatan Pengobatan Pada Wanita Penderita Kanker Payudara Di Rumah Sakit Umum Daerah Simeulue Tahun 2018. Jurnal Info Kesehatan Vol 17, $\quad$ No.1. https://doi.org/10.31965/infokes.Vol17.I ss1.240 Diakses 22 Januari 2020.

Kementrian Kesehatan RI. (2013). Riset Kesehatan Dasar (RISKESDAS). Jakarta: Badan Litbang. Kemenkes RI. http://www.depkes.go.id/resources/down load/general/HasilRiskesdas Diakses 15 April 2019

(2018). Riset Kesehatan Dasar (RISKESDAS). Jakarta: Badan Litbang. Kemenkes RI. https://dinkes.kalbarprov.go.id/wpcontent/uploads/2019/03/LaporanRiskesdas-2018-Nasional.pdf. Diakses 03 Oktober 2019

Kirana, AL. (2016). Dukungan Sosial dan Resilliensi Pada Pasien Kanker Payudara (Studi Kasus Pada Pasien Kanker Payudara yang Menjalani Kemoterapi. Jurnal Psikoborneo, 4(4), 829-837. http://ejournal.psikologi.fisipunmul.ac.id Diakses Januari 2020.

Otto Shirley E. (2015). Buku Saku Keperawatan Onkologi. Cetakan ke-5. Jakarta: EGC.

Paratika, S., Ernawaty. (2018). Hubungan Karakteristik Pasien Human Immunodeficiancy Virus (Hiv) Dengan
Pengambilan Keputusan Pengobatan Di Puskesmas Dupak. Indonesian Journal of Public Health, Vol 13, No 1. 61-72. https://e-

journal.unair.ac.id/IJPH/article/view/727 3/0 Diakses 20 Januari 2020

Kim, H. S., Kim, J. H., Kim, J. W., \& Kim, B. C. (2016). Chemotherapy in elderly patients with gastric Cancer. Journal of Cancer, $\quad 7(1), \quad 88-94$. https://www.ncbi.nlm.nih.gov/pmc/articl es/PMC4679385/.Diakses 20 April 2019

Kolin, M. Y., Warjiman, W., \& Mahdalena, M. (2017). Kualitas Hidup Pasien Kanker Yang Menjalani Kemoterapi. Jurnal Keperawatan Suaka Insan (JKSI), 1(1), 1-12. Retrieved from https://journal.stikessuakainsan.ac.id/ind ex.php/jksi/article Diakses 21 Januari 2020

Kowalak, J. P., Welsh, W., \& Mayer, B. (2011). Buku Ajar Patofisiologi. Jakarta: EGC

Kubler-Ross, E. (1969). On Death and Dying. Now York: Macmillan

Manshaee, G \& Amini, K. (2013). The Relationship between Spirituality whit Emphasis on Religius Orientation and Psychosomatic Disorder (Asthma, Migraine, and Blood Pressure). Journal Procelia-Social and Behavioral Sciences, $\quad 84$ : 1260-1264. https://www.sciencedirect.com Diakses 21 Januari 2020.

Margaret A, L., Mitchell, M. (2004). Psychosocial Impact of Cancer in Low-Income Rural/Urban Women:Phase II. Capstone College of Nursing, University of Alabama. https://www.researchgate.net Diakses 20 Januari 2020.

Notoatmodjo, Soekidjo. 2003. Pendidikan Dan Perilaku Kesehatan. Rineka Cipta: Jakarta.

Nurpeni, M. K. R., Prapti , G. K. N., Kusmarjathi, K. N. (2014). Hubungan Dukungan Keluarga Dengan Tingkat Kecemasan Pada Pasien Kanker Payudara (Ca Mammae) Di Ruang Angsoka Iii Rsup Sanglah Denpasar. Coping. Vol. 2, No. 3. 
https://ojs.unud.ac.id/index.php/coping

Diakses 20 Januari 2020

Permanawati, Y., \& Hertinjung, W. S. (2015).

Kesejahteraan Subjektif Pada

Penyandang Kanker Payudara. Jurnal

Indigenous. 13(1), 60-71.

journals.ums.ac.id/index.php/indigenous

/article/view/2324. Diakses 20 Januari

2020

Rahayuwati, L., Ibrahim, K., Komariah, M. (2017). Pilihan Pengobatan Pasien Kanker Payudara Masa Kemoterapi: Studi Kasus. Jurnal Keperawatan Indonesia. Volume 20 No 2. hal 118127. http://jki.ui.ac.id. Diakses 20 Januari 2020

Razali, R. M., Bee, P. C., \& Gan, G. G. (2013). Surveys of willingness to accept chemotherapy among elderly Malaysian patients. Asian Pacific Journal of Cancer Prevention, 2029-2032. https://www.researchgate.net Diakses 20 Januari 2020.

Saniatuzzulfa, Rahmah., Retnowati, Sofia (2015). Program "Pasien Pandai" Untuk Meningkatkan Optimisme Pasien Kanker. Gadjah Mada Journal Of Professional Psychology. https://Journal.Ugm.Ac.Id/Gamajpp/Arti cle Diakses 20 Agustus 2019

Santi, S. M. P. L., dan Sulastri. (2010). Gambaran Fisik dan Psikologis Klien dengan Kanker Serviks di RSUD Dr. Moewardi. Publikasi Ilmiah, Vol. 03. https//publikasiilmish.ums.ac.id Diakses 20 Agustus 2019

Sari, L. T. (2019). Hubungan Motivasi Kesembuhan Dengan Kepatuhan Minum Obat Pada Penderita Tb Paru Dewasa. JuKe Vol. 3 No. 1. http://jurnal.stikesganeshahusada.ac.id/i ndex.php/juke/article Diakses 20 Januari 2020.

Sasongko, A. (2010). Temuan Baru, Interaksi Sosial Kunci Sembuhkan Pasien Kanker. Republika Online. http://republika.co.id. Diakses 05 Februari 2020.
Schiffman, Kanuk. (2007). Perilaku Konsumen. dialihbahasakan oleh Zulkifli Kasip. Edisi Ketujuh: PT. Indexs.

Smeltzer \& Bare. (2008). Buku Ajar Keperawatan Medikal Bedah. Jakarta. EGC.

Solomon, M., Gary, B., Soren, A., and Margaret, K, Hogg., 2006. Consumer Behavior A European Perspective: Third Edition. Pearson Education Limited.

Song, L., Son, J., \& Lin, N. (2011). Social Support. London; Sage.

Tomey, A.M., \& Alligood, M.R. (2014). Nursing theorists and their work.6th ed. USA: Mosby Elsevier.

Wardani, E, K. (2014). Respon Fisik dan Psikologi Wanita dengan Kanker Serviks yang Telah Mendapat Kemoterapi di Rsud Dr Moewardi Surakarta. Universitas Muhammadiyah Surakarta. http://eprints.ums.ac.id/30730 Diakses 14 Agustus 2019

Wulandari, N., Bahar, H.,Ismail, S, C. (2017). Gambaran Kualitas Hidup pada Penderita Kanker Payudara di Rumah Sakit Umum Bahteramas Provinsi Sulawesi Tenggara Tahun 2017. JIMKESMAS. Vol 2, No 6. https://media.neliti.com . Diakses 20 Januari 2020

Yani, D. I. (2007). Pengalaman Hidup Klien Kanker Serviks di Bandung. Fakultas Ilmu Keperawatan Universitas Padjajaran.

https://www.scribd.com/doc/225481634 Diakses 20 Januari 2020

Yanti, M. A. D., Kholimah, S. (2016). Hubungan Dukungan Keluarga Dengan Pengobatan Kanker Serviks. Jurnal Ilmiah Kesehatan. Vol 5, No.9. https://www.researchgate.net/publicatio n Diakses 20 Januari 2020

Yaribeygi, H., Panahi, Y., Sahraei, H., Johnston, P, T., Sahebkar, A. (2017). The Impact Of Stress On Body Function: A Review. EXCLI Journal. ISSN 1611-2156. https://www.ncbi.nlm.nih.gov/pmc/articl es Di akses 12 Oktober 2019 